\title{
A direct binding assay for rheumatoid factor serum antiglobulins using fluorescein-labelled Fc fragment of human immunoglobulin-G
}

\author{
IRENE SINGH AND G. E. FRANCIS
}

\begin{abstract}
From the Department of Biochemistry and Chemistry, Medical College of St Bartholomew's Hospital, London ECIM 6BQ, UK
\end{abstract}

SUMMARY A simple routine method is described for the quantitation of antiglobulin (rheumatoid factor) in human serum irrespective of its immunoglobulin class. Papain Fc fragment of human IgG is labelled with fluorescein isothiocyanate and incubated with the serum. Bound Fc is separated from free Fc by precipitation with polyethylene glycol and measured by the fluorescence of the precipitate. Results are expressed as a percentage of the binding obtained with a normal pool serum. About $60 \%$ of seronegative rheumatoid sera and $96 \%$ of seropositive rheumatoid sera gave results more than $2 \mathrm{SD}$ above the mean value for normal sera. Only $17 \%$ of osteoarthritic sera gave positive results by the same criterion. A relationship is also deduced to show that if the test is carried out at a number of Fc concentrations a double reciprocal plot of bound Fc against free Fc enables both the total antiglobulin and the ratio of binding constants of antiglobulin for Fc and for IgG to be calculated. This ratio is approximately unity. Under the standard conditions the results correspond to a measurement of approximately $30 \%$ of the total antiglobulins present.

The presence in the serum of autoantibodies reacting with human IgG and at least in part (Normansell, 1971, 1972) with heterologous IgGs is a characteristic feature of rheumatoid arthricis (RA). Low levels of antiglobulin are commonly found in normal sera, particularly among the older population, and raised levels in certain other diseases, for example, systemic lupus erythematosus.

These antiglobulins may be of the IgM, IgG, and IgA classes (Torrigiani et al., 1970), present in varying proportions in any one serum. Where IgG predominates, the conventional latex and red cell agglutination tests are usually negative owing to the much lower efficiency of the bivalent IgG antibody in causing agglutination. Since about $20-30 \%$ of patients with RA are seronegative by agglutination tests but possess serum antiglobulins it would be of considerable diagnostic value if a rapid and easy routine test were available for the detection and quantitation of all classes of rheumatoid factor (RF) antiglobulins.

The method of Torrigiani et al. (1970) involves absorbing the antiglobulins from the serum with an

Received for publication 20 March 1978 insolubilised $\gamma$-globulin preparation, eluting the absorbed antiglobulins, and measuring the IgG, IgM, and IgA concentrations in the eluate by radial immunodiffusion against gelified specific antisera to each class.

Hay et al. (1975) have described a solid phase radioimmunoassay sandwich technique in which plastic tubes are coated with a $\gamma$-globulin preparation which in turn absorbs the antiglobulins from the serum. The amounts of each class of antiglobulin absorbed are measured in terms of the weights of radiolabelled specific antibody to each class that the tubes will subsequently bind. Alternatively, the total absorbed antiglobulin may be measured using labelled antibody to L-chains only.

Both these methods use a heterologous antigen, but Carson et al. (1977) have described a modification of Hay's method using papain digest Fc fragment of human IgG as the antigen. This modification, however, requires a far more complex preparation of labelled specific antibody.

The present communication describes a direct competitive binding assay, using as antigen the Fc fragment of human IgG labelled with fluorescein. Antiglobulin is measured regardless of class, and no specific antibodies are required 
Material and methods

TEST SERA

Sera from patients with definite RA only were used, seropositive and seronegative by latex and/or sheep cell agglutination tests, and from osteoarthritic patients. Fresh normal sera were obtained from a blood bank. All sera were stored at $-20^{\circ} \mathrm{C}$ and not normally used after more than one freezing and thawing. Thawing was carried out by agitation at $37^{\circ} \mathrm{C}$ to minimise any possible loss of RFcryoglobulins (Marcus and Townes, 1971). All sera were centrifuged at $2500 \mathrm{~g}$ before use.

\section{ANTISERA}

Rabbit antiserum to human $\gamma$-globulin was raised following Kwapinsky's (1972) immunisation schedule; serum was collected seven to 10 days after the last injection. Swine anti-human-Fab serum was obtained from Nordic Immunological Laboratories, Maidenhead, Berks.

$\gamma$-GLOBULIN AND FC FRAGMENTS

Equine $\gamma$-globulin was prepared from whole horse serum dialysed at $4^{\circ} \mathrm{C}$ for two days against $0.01 \mathrm{M}$ phosphate buffer $\mathrm{pH} 8.0$ and centrifuged at $1875 \mathrm{~g}$ for 15 minutes, on a DEAE-cellulose column $(10 \mathrm{ml}$ dialysed serum to $14 \mathrm{~g}$ wet weight of Whatman DE-52) equilibrated with the same buffer. The $\gamma$-globulin fraction eluted as a single sharp peak with the same buffer.

Human $\gamma$-globulin (Cohn Fr II) was obtained from Miles Pentex Inc.

Heat denaturation was carried out on $1 \%$ solutions of $\gamma$-globulin in $0.075 \mathrm{M}$ phosphate, $0.075 \mathrm{M}$ $\mathrm{NaCl}$ buffer pH 7.0 for one hour at $60^{\circ} \mathrm{C}$.

Papain digestion followed the method of Porter (1959); Fc fragment was separated on a Whatman DE-52 column (Longmire et al., 1971). The purity of the preparations was checked by immunoelectrophoresis with antisera to whole human $\gamma$-globulin and its Fab fragment; normally, no more than an occasional trace of Fab fragment impurity was found.

\section{DILUENT}

All reagents and solutions for the assay were made in $0 \cdot 1 \mathrm{~m}$ borate buffer $\mathrm{pH} 8 \cdot 3-8 \cdot 5$ (borax $9.536 \mathrm{~g}$, boric acid $6.184 \mathrm{~g}, \mathrm{NaCl} 4.384 \mathrm{~g}, \mathrm{NaN}_{3} 0.200 \mathrm{~g}$, made up to 1 litre).

SODIUM DECYL SULPHATE (SDS)

This was prepared from decan-1-o1 (BDH Ltd) by the method of Dreger et al. (1944) and recrystallised twice from $95 \%$ ethanol.
SODIUM DODECYL SULPHATE (SLS)

Sodium lauryl sulphate, specially pure, was obtained from BDH Ltd.

FLUORESCENT LABELLING OF FC FRAGMENT Following essentially the method of Wood et al. (1965), the following conditions were found to give consistent labelling at an approximately 1:1 molar ratio of fluorescein to protein. The Fc peak from the column was concentrated to about $25 \mathrm{mg}$ per ml (absorbance measurements at $280 \mathrm{~nm} ; 1 \%$ specific absorbance $=10 \cdot 0$ ). A 10 -fold concentrate of a $\mathrm{Na}_{2} \mathrm{CO}_{3}-\mathrm{NaHCO}_{3}(\mathrm{I}=0 \cdot 1, \mathrm{pH} 9 \cdot 6)$ buffer was added, $0.1 \mathrm{ml}$ for each $1 \mathrm{ml}$ of Fc solution, and the alkaline protein was added to a small stoppered conical flask in which an acetone solution of fluorescein isothiocyanate (FITC) (isomer, I, BDH Ltd) had been evaporated using a $40: 1(w / w)$ FITC to protein ratio. After stirring with a small magnetic stirrer until all FITC had dissolved the solution was left at room temperature for two hours and unbound fluorescein was removed on a $2.5 \times 25 \mathrm{~cm}$ column of Sephadex G-50 equilibrated in borate- $\mathrm{NaCl}$ buffer; the first of the two yellow bands passing down the column contained the labelled Fc.

Ultracentrifugal examination of this material showed it to be monodisperse with $S=4 \cdot 1$.

All preparations containing fluorescent protein were kept in the dark as far as possible.

\section{MEASUREMENT OF FLUORESCEIN:PROTEIN RATIO}

The protein content of fluorescent protein preparations was determined by microKjeldahl, assuming a nitrogen content of $16 \%$, and the fluorescein content by absorbance measurements at the wavelength of maximum absorption, $495 \mathrm{~nm}$. The molar specific absorbance of pure FITC $\left(8.67 \times 10^{4}\right)$ was used for the calculation, but since the specific absorbance of fluorescein bound to protein is slightly lower than that of pure FITC and varies somewhat with the degree of labelling and the source of the protein, the values calculated may be as much as $20 \%$ lower than the true value (McKinney et al., 1964).

These preparations possessed an adequate degree of fluorescence for the assay; preparations with higher fluorescein content gave greater extents of nonspecific co-precipitation in the assay. A few of the experiments reported here employed preparations with higher fluorescein contents, giving higher normal serum binding levels, but this does not invalidate the conclusions drawn from these experiments.

MEASUREMENT OF FLUORESCENT PROTEIN All measurements of fluorescence were made on a 
double monochromator Zeiss spectrophotometer with fluorescence attachment. The excitation and emission maxima for FITC-Fc (Fc*) were found to be at 495 and $519 \mathrm{~nm}$ respectively, but blank assays with the omission of Fc* carried out at these wavelengths invariably gave small positive values due to Tyndall scattering. This was eliminated by reducing the excitation wavelength to $448 \mathrm{~nm}$ while keeping the emission wavelength at $519 \mathrm{~nm}$. Fluorescence measured at these wavelengths was approximately $60 \%$ of that measured at the maxima, and these wavelengths were used in all subsequent measurements.

Linearity of the fluorimeter response was checked by measurements on appropriate dilutions of $\mathrm{Fc}^{*}$ in borate buffer containing SLS. It was found to be strictly linear over the whole range of concentrations used.

Since the assay is made on a dilute solution of a very small protein precipitate any fluorescence quenching due to other serum proteins or unknown substances present in the serum should be negligible, and the fluorescence measurement may therefore be taken as a direct measurement of the amount of $\mathrm{Fc}^{*}$ present in the precipitate.

\section{ASSAY METHOD}

This is an adaptation of the antigen-bindingcapacity method for the measurement of antibodies to low molecular weight antigens described by Farr (1958) and modified by Mulligan et al. (1966) and Creighton et al. (1973). Fluorescent $\mathrm{Fc}\left(\mathrm{Fc}^{*}\right)$ is added to normal and test serum in the presence of a low concentration of SDS and competes for the IgG binding sites on RF molecules with the serum IgG already present. Bound and free Fc* are separated by precipitation with polyethylene glycol 6000 (PEG; BDH Ltd), and the bound Fc* in the washed precipitates is measured after solution in SLS.

To $0.1 \mathrm{ml}$ of serum in a $15 \mathrm{ml}$ tapered centrifuge tube are added, in order, $0.1 \mathrm{ml} \mathrm{SDS,} 5 \times 10^{-5} \mathrm{M}$ in borate buffer, and $250 \mu \mathrm{g} \mathrm{Fc} *$ of the appropriate preparation in $0.5 \mathrm{ml}$ buffer, mixing well after each addition. After incubation at $37^{\circ} \mathrm{C}$ for one hour and at $4{ }^{\circ} \mathrm{C}$ for 30 minutes $0.7 \mathrm{ml}$ of $15 \%$ PEG solution in borate buffer is added with immediate and thorough mixing. After standing at room temperature for one hour the mixture is centrifuged at $2500 \mathrm{~g}$ for 30 minutes at $15^{\circ} \mathrm{C}$, the clear supernatant is removed by suction, with care not to disturb the precipitate, and this is washed once by resuspension in $1 \mathrm{ml}$ of $7.5 \%$ PEG in buffer and recentrifugation. After removing the washing as before the precipitate is dissolved in $3.0 \mathrm{ml}$ of $0.5 \%$ SLS in buffer with a short incubation at $37^{\circ} \mathrm{C}$ if necessary to dissolve the precipitate completely. The fluorescence of this solution is then read with the fluorimeter sensitivity adjusted to give 100 scale deflection with a suitable dilution of the $\mathrm{Fc}^{*}$ antigen, commonly about $12-25$ $\mu \mathrm{g} \mathrm{Fc} *$ in $3 \mathrm{ml}$.

The results are expressed as a percentage of the binding observed with normal pool serum.

The effect of varying different parameters in the assay was investigated to find the conditions giving the lowest normal serum binding and standard deviation, coupled with the highest possible percentage of normal binding by rheumatoid sera.

\section{Results}

SOLUBILITY OF FC* IN PEG

The solubility properties of $\mathrm{FC}^{*}$ were studied, both with and without the presence of normal serum, to assess the significance of any 'blank' contribution to the finally measured fluorescence.

Although partially precipitated by $40 \%$ saturated ammonium sulphate, $\mathrm{Fc}^{*}$ is completely soluble in concentrations of PEG up to $20 \%$. A blank assay with omission of serum gave a zero reading.

Solubility measurements in the presence of serum, that is, nonspecific co-precipitation, are complicated by the presence of low levels of antiglobulin even in normal serum. However, that a part of the normal serum values obtained is due to nonspecific coprecipitation is indicated by experiments using normal rabbit serum in place of human serum, where positive results were also obtained at a level approximately half that obtained with normal human serum.

EFFECT OF VARYING PEG CONCENTRATION Creighton et al. (1973) have shown that an IgG trimer is largely precipitated by $7.5 \%$ PEG concentration whereas only about $10-15 \%$ of human IgG itself is precipitated.

A complex of IgG class RF with $\mathrm{Fc}^{*}$ or with $\mathrm{Fc}^{*}$ and IgG will be smaller than an IgG trimer, so several PEG concentrations were used to establish the optimal concentration for distinguishing normal from rheumatoid sera.

Two seronegative RA sera and one normal serum having the same binding value as the mean of 23 normal sera were assayed using PEG concentrations of $7.5 \%, 10 \%$, and $20 \%$ for the precipitation. No seropositive RA sera, with mainly IgM-RF, were included in this experiment since IgM, although not so readily precipitated by very low PEG concentrations as its very high molecular weight would lead one to expect, is nevertheless more readily precipitated by PEG than is IgG (Zubler et al., 1977). There is, therefore, no problem in separating IgM-RF 
complexes with $\mathrm{Fc}^{*}$ from free $\mathrm{Fc}^{*}$ or non-RF IgG.

Table 1 shows that the differences in binding between normal and RA sera were very similar with $7.5 \%$ and $10 \%$ PEG, but that at $7.5 \%$ PEG a markedly lower value was obtained for the normal serum. At $20 \%$ PEG the difference was considerably less, and the normal serum value was slightly higher than at $10 \%$ PEG. Using only $4 \%$ PEG in order to reduce the nonspecific co-precipitation still further gave a much wider range of values with normal sera and too much overlap between the normal and pathological ranges to make the results of any significance.

Table 1 Effect of PEG concentration on Fc* binding by two seronegative $R A$ sera and normal serum

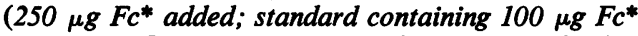
set to give fluorimeter reading of 100; 2SD of values for 23 normal sera at $7.5 \%$ PEG $=25 \%$ of mean value)

\begin{tabular}{|c|c|c|c|c|}
\hline \multirow{2}{*}{$\begin{array}{l}P E G \\
\text { con. } \\
(\%)\end{array}$} & \multirow[t]{2}{*}{ Serum } & \multicolumn{3}{|l|}{$F c^{*}$ bound } \\
\hline & & $\stackrel{\mu g}{\text { (duplicates) }}$ & $\begin{array}{l}\mu g \text { excess over } \\
\text { mean normal }\end{array}$ & $\begin{array}{l}\text { as } \% \text { of } \\
\text { mean normal }\end{array}$ \\
\hline $7 \cdot 5$ & $\begin{array}{l}\text { RA } 1 \\
\text { RA 2 } \\
\text { Normal }\end{array}$ & $\begin{array}{l}22.0 ; 23.0 \\
41 \cdot 5 ; 45.0 \\
16.0 ; 19.0\end{array}$ & $\begin{array}{r}5 \\
26 \\
-\end{array}$ & $\begin{array}{l}139 \\
285 \\
100\end{array}$ \\
\hline & $\begin{array}{l}\text { RA } 1 \\
\text { RA } 2\end{array}$ & $\begin{array}{l}49.0 ; 49.0 \\
74.0 ; 74.0\end{array}$ & $\begin{array}{r}5 \\
30\end{array}$ & $\begin{array}{l}119 \\
182\end{array}$ \\
\hline 10 & Normal & $43.0 ; 45.0$ & $\frac{1}{3.5}$ & 100 \\
\hline \multirow[t]{2}{*}{20} & $\begin{array}{l}\text { RA 1 } \\
\text { RA } 2\end{array}$ & $\begin{array}{l}52.5 ; 52.5 \\
62.5 ; 62.5\end{array}$ & $1^{3 \cdot 5}$ & $\begin{array}{l}112 \\
133\end{array}$ \\
\hline & Normal & $49.5 ; 49.0$ & - & 100 \\
\hline
\end{tabular}

EFFECT OF VARYING FC* CONCENTRATION At any levels of IgG and RF found in serum a considerable proportion of the RF binding sites will be bound to IgG molecules, and the significant reaction with $\mathrm{Fc}^{*}$ will therefore be a displacement rather than a direct association. The higher the concentration of $\mathrm{Fc}^{*}$ used, the more effective should be the displacement reaction, the smaller should be the effect of variations in the serum IgG concentration, but the larger will be the extent of nonspecific co-precipitation or adsorption on the PEG precipitate. An Fc* addition of $400 \mu \mathrm{g}$ to the $0.1 \mathrm{ml}$ of serum used in the assay would constitute an approximately equimolar $\mathrm{Fc}^{*}$ and IgG concentration in a serum with $12 \mathrm{mg}$ per $\mathrm{ml} \mathrm{IgG}$. To find the optimal conditions, a standard assay was carried out on one normal and one seronegative RA serum with a number of $\mathrm{Fc}^{*}$ concentrations. Figure 1 shows that the total $\mathrm{Fc}^{*}$ binding, with both the normal and the RA serum, decreases with decreasing $\mathrm{Fc}^{*}$ concentration, but the binding with RA serum, expressed as a percentage of normal binding, increases.

In experiments with less than $100 \mu \mathrm{g} \mathrm{Fc}$ * the range of values obtained with normal sera was much

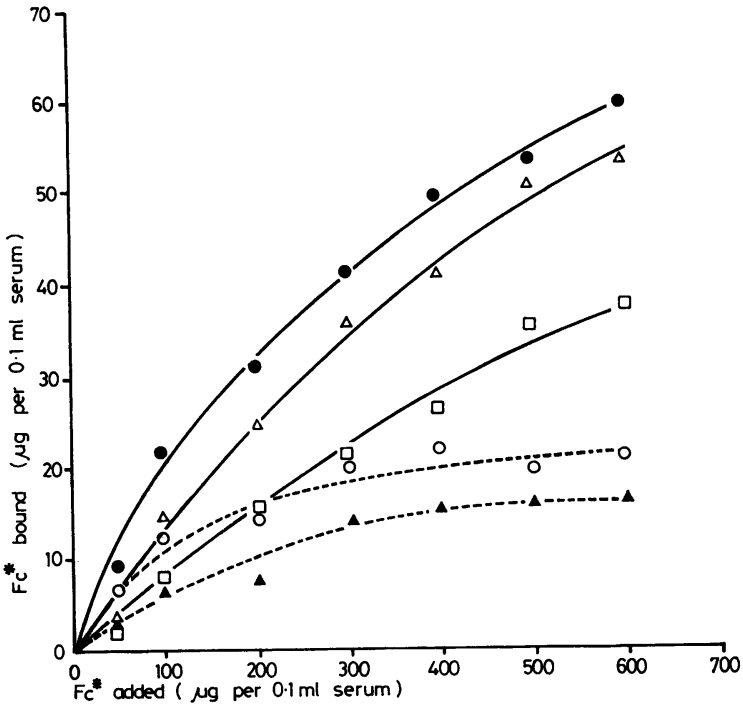

Fig. $1 \quad F c^{*}$-binding as function of $F c^{*}$ added: Seropostive $R A$ serum $-\triangle-\triangle-$; seronegative $R A$ serum - - - ; normal serum with same binding as mean of 25 individual normal sera $-\square-\square-$.

Difference between seropositive $R A$ and normal serum ... $\Delta \ldots \Delta \ldots$. . difference between seronegative $R A$ and normal serum . . $\bigcirc \ldots \bigcirc \ldots$

wider than with $250 \mu \mathrm{g}$ or above. Since the difference in binding values was constant from about $300 \mu \mathrm{g}$ upwards the value of $250 \mu \mathrm{g}$ was chosen for the assay.

\section{EFFECT OF SODIUM DECYL SULPHATE ON SPECIFIC BINDING}

Both SDS and SLS are effective reagents for minimising protein-protein interactions, but SDS, being the less effective of the two, will have effects which are more concentration-dependent. Low concentrations of SDS were therefore used to reduce nonspecific binding without any comparable reduction in specific binding.

When SDS at concentrations up to $5 \times 10^{-2} \mathrm{M}$ was included in the assay system (Table $2 \mathrm{~A}$ ) the maximum effect at differentiating between normal and RA sera without reducing the specific binding was observed at about $5 \times 10^{-5} \mathrm{M}$. In other experiments with a bovine serum albumin anti-bovine serum albumin system this concentration was also shown to have no effect in a quantitative precipitin reaction and not to reduce the intensity of the precipitation lines in an Ouchterlony double diffusion. Table 2B shows the results of an assay on a pool of 50 normal sera and three seronegative 
Table 2 Effect of sodium decyl sulphate on Fc* binding: $(A)$ effect of varying concentrations of SDS on net binding (total binding minus binding by pool of 50 normal sera) with one seropostive and one seronegative $R A$ serum; $(B)$ effect of $5 \times 10^{-5} M$ $S D S$ on binding by pooled normal serum and three seronegative $R A$ sera

\begin{tabular}{|c|c|c|}
\hline \multirow{2}{*}{$\begin{array}{l}\text { (A) } \\
\text { Conc. of } S D S(M)\end{array}$} & \multicolumn{2}{|c|}{ Specific binding of $F c^{*}(\mu \mathrm{g} / 0.1 \mathrm{ml})$} \\
\hline & Seropositive $R A$ serum & Seronegative $R A$ serum \\
\hline - & $11 \cdot 8$ & $1 \cdot 3$ \\
\hline $5 \times 10^{-9}$ & $14 \cdot 8$ & $2 \cdot 8$ \\
\hline $5 \times 10^{-8}$ & $15 \cdot 8$ & $2 \cdot 8$ \\
\hline $5 \times 10^{-7}$ & $14 \cdot 0$ & $2 \cdot 0$ \\
\hline $5 \times 10^{-6}$ & $15 \cdot 5$ & $2 \cdot 8$ \\
\hline $5 \times 10^{-5}$ & $14 \cdot 0$ & $3 \cdot 3$ \\
\hline $5 \times 10^{-4}$ & $13 \cdot 0$ & $3 \cdot 3$ \\
\hline $5 \times 10^{-3}$ & $10 \cdot 3$ & $2 \cdot 0$ \\
\hline $5 \times 10^{-2}$ & $4 \cdot 3$ & 0.0 \\
\hline
\end{tabular}

\begin{tabular}{llll}
\hline $\begin{array}{l}\text { (B) } \\
\text { Serum }\end{array}$ & $\begin{array}{l}\text { Fc bound } \\
\text { (i) Without SDS; (ii) With } 5 \times 10^{-5} M S D S\end{array}$ \\
\cline { 2 - 4 } & $\mu g / 0.1 \mathrm{ml}$ & $\begin{array}{l}\mu \mathrm{\mu} \text { in excess } \\
\text { of normal } / 0.1 \mathrm{ml}\end{array}$ & as $\%$ of normal \\
\hline Normal & (i) 19.5 (ii) 17.5 & - & 100 \\
RA1 & (i) 23.5 (ii) 22.5 & (i) 4.0 (ii) 5.0 & (i) 120 (ii) 129 \\
RA 2 & (i) 21.5 (ii) 20.5 & (i) 2.0 (ii) 3.0 & (i) 110 (ii) 117 \\
RA 3 & (i) 46.5 (ii) 43.5 & (i) 27 (ii) 26 & (i) 238 (ii) 249 \\
\hline
\end{tabular}

RA sera with the inclusion of $5 \times 10^{-5} \mathrm{M}$ SDS and without SDS. The advantage of including SDS is small but significant.

\section{EFFECT OF AGE ON BINDING BY NORMAL SERA}

Sera from 32 normal subjects in the age range 50-60 years and from 30 subjects in the age range 2030 years were tested. The older age group had a mean binding level approximately $15 \%$ higher than the other, and a slightly wider range of values. The difference between the mean values for the two groups was significant at $\mathbf{P}<0.001$. Normal sera for use in the assay were therefore chosen exclusively from the 50-60 years age group to obtain the most conservative normal level, thus avoiding false-positive results in the older age groups where rheumatic conditions are most common.

\section{BINDING OF OTHER TYPES OF FC* FR A GMENT}

A comparison was made of the binding by 10 normal and 10 seronegative RA sera of $\mathrm{Fc}^{*}$ prepared from heat-denatured and from undenatured human $\gamma$-globulin, and a similar comparison (with a different set of sera) using $\mathrm{Fc}^{*}$ from heat-denatured human $\gamma$-globulin and from undenatured equine $\gamma$-globulin, in view of the use of equine $\gamma$-globulin by Torrigiani et al. (1970).
The results (Fig. 2) show that the heat-denatured human $\gamma$-globulin yields the best antigen of the three, giving positive results with seven out of 10 and eight out of 10 above normal mean +2 SD for the RA sera whereas the undenatured human antigen and the horse antigen pick up only four and three out of 10 respectively. The denatured human antigen also gives the lowest normal serum binding of the three (all three antigens possessed the same fluorescein: protein ratio), which is probably the main cause of its greater efficiency since there is no evidence of any conformational changes in the Fc region leading to changes in antigenic specificity when IgG undergoes heat denaturation (Eisenberg, 1976). It is also noteworthy that the equine antigen with five out of 10 of the seronegative RA sera actually gives a lower binding than the normal mean and is evidently a far inferior antigen.

\section{TEST OF FINALISED ASSAY SYSTEM ON} NORMAL AND PATHOLOGICAL SERA Fifty normal, 26 seropositive, and 23 seronegative RA sera and 23 osteoarthritic sera were assayed by the finalised method using $\mathrm{Fc}^{*}$ from heat-denatured human $\gamma$-globulin (Fig. 3).

Since there is a range of binding values for the normal sera the titres for the pathological sera are expressed as a percentage of the normal mean. A $95 \%$ confidence limit can be taken that the serum is abnormal if its titre exceeds the normal mean by twice the SD of the normals (SD calculated as usual for an asymmetric distribution as antilog of SD of mean of logs of individual values).

Both the seropositive and the seronegative groups were significantly different from the normal group. For both groups the median value differed from that of the normals with $P$ less than 0.001 by the Chi-squared test.

On the criterion of a $95 \%$ confidence limit of $+2 \mathrm{SD}$ of the normal mean, the seropositive group had $96 \%$ above this limit, the seronegative group $60 \%$. The osteoarthritic group had a median value slightly higher than the normals, but only four out of $23(17 \%)$ exceeded the normal mean by more than 2 SD.

ABSOLUTE VALUES FOR RF CONCENTRATION AND K FOR THE DISPLACEMENT REACTION To obtain an absolute value for antibody concentration by an antigen-binding assay method it is necessary that all the antibody combining sites be saturated with the added labelled antigen as in Osler's modification of the Farr antigen-bindingcapacity method (Mulligan et al., 1966) and that all the bound labelled antigen be precipitated. The second criterion appears to be satisfied at $7.5 \%$ 


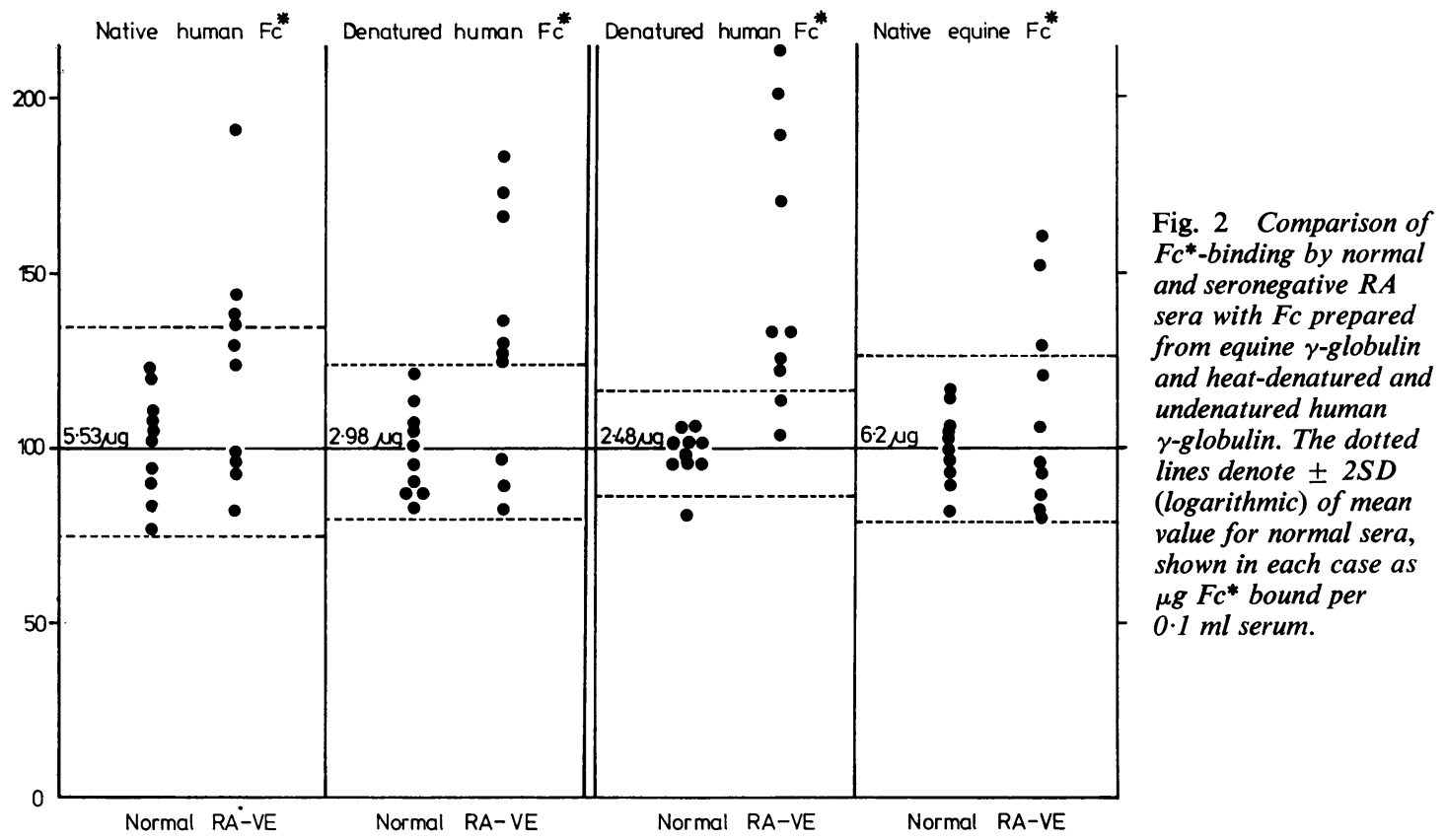

PEG (Table 1) but saturation of the binding sites could be obtained only at an impossibly high $\mathrm{Fc}^{*}$ concentration owing to the competing serum IgG. However, by carrying out the assay at a number of $\mathrm{Fc}^{*}$ concentrations and plotting the reciprocal of the bound $\mathrm{Fc}^{*}$ against the reciprocal of the free $\mathrm{Fc}^{*}$ at equilibrium, straight-line graphs should be obtained from which the total concentration of antibodycombining sites in the serum, and the equilibrium constant for the reaction can both be obtained (see Appendix).

Figure 4 shows the results of one such experiment in which pooled normal serum and a high binding latex seronegative RA serum were assayed using amounts of $\mathrm{FC}^{*}$ from 240 to $2750 \mu \mathrm{g}$ in $0.5 \mathrm{ml}$ buffer. Extrapolation of the best fit lines to 'reciprocal of free $\mathrm{Fc}^{*}=0$, that is, infinite excess $\mathrm{Fc}^{*}$, gives bound $\mathrm{Fc}^{*}=0.00111 \mu \mathrm{mol}$ per $0.1 \mathrm{ml}$ serum or $833 \mu \mathrm{g}$ RF per ml serum (RA serum) and $0.000578 \mu \mathrm{mol}$ per $0.1 \mathrm{ml}$ serum or $434 \mu \mathrm{g}$ apparent $\mathrm{RF}$ per $\mathrm{ml}$ (normal serum), assuming in each case a molecular weight of 75000 for the half IgG molecule containing one binding site. This difference of $399 \mu \mathrm{g}$ per $\mathrm{ml}$ is somewhat above that of any of the sera examined by Torrigiani et al. (1970), but their values may have been low owing to the use of a heterologous antigen or to loss of antiglobulin during the reconcentration of the eluate before measurement by radial immunodiffusion. The high absolute values for the two sera are undoubtedly due to nonspecific co-precipitation in the two cases.

If the $\mathrm{Fc}^{*}$ binding is compared for the two sera at the level of $250 \mu \mathrm{g} \mathrm{Fc}^{*}$ used in the standard test and at the extrapolation value of infinite excess $\mathrm{Fc}^{*}$, the ratios of RA serum binding to normal serum binding are found to be 1.80 (at $250 \mu \mathrm{g}$ ) and 1.89 (at infinite excess); 2 SD for the normal serum was 0.28 .

The intercepts on the reciprocal of free $\mathrm{Fc}^{*}$ axis, equal to $\mathrm{K} /$ total IgG concentration, are -166 and -160 , which with the total IgG concentrations (determined with a commercial radial immunodiffusion kit) of 10 and $13 \mathrm{mg}$ per $\mathrm{ml}$ respectively give values of $\mathrm{K}$ of 1.10 (normal) and 1.39 (rheumatoid). This difference is probably not significant; the results indicate that the association constants of the antiglobulin with the labelled Fc preparation and with normal IgG are very similar. That with $\mathrm{Fc}^{*}$ may actually be slightly the greater.

\section{Discussion}

The detection and measurement of serum antiglobulins is rendered difficult by the presence in the serum of the homologous antigen, IgG. Previous approaches to the problem have involved separation of the antiglobulins by an immobilised. usually 


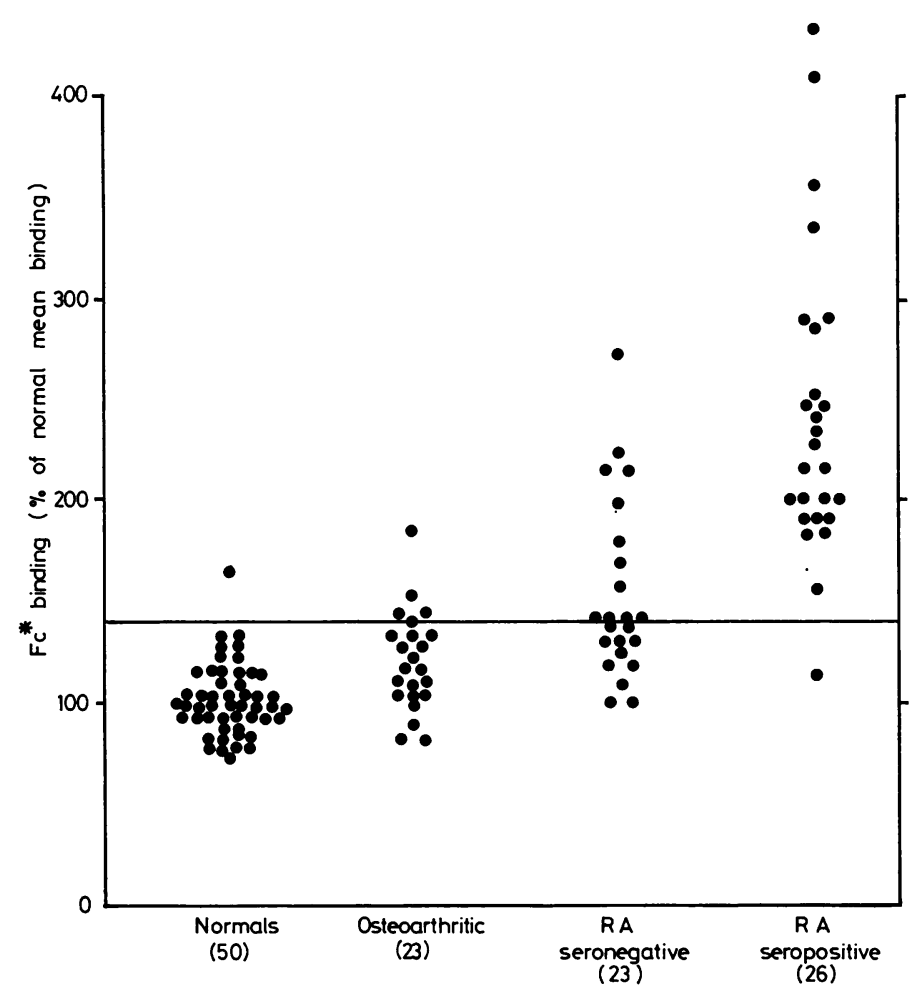

Fig. 3 Binding of $\mathrm{Fc}^{*}$ by normal, osteoarthritic, $R A$ seronegative and $R A$ seropositive sera as percentage of mean binding by normal sera. The horizontal line represents $+2 S D$ (logarithmic) of the normal mean binding. heterologous, antigen, rabbit or horse IgG. This is open to objection since there is no guarantee that anti-human IgG will react equally with the homologous antigens. Indeed, Normansell (1972) has shown that in a single rheumatoid serum, although most of the RF antiglobulin reacted with both human and rabbit IgG, a small proportion reacted with the human IgG only and a further small proportion with rabbit IgG only. Torrigiani et al. (1970) also showed differences in the amounts of IgM, IgG, and IgA antiglobulins measured in normal, rheumatoid, and osteoarthritic sera according to whether they were separated by absorption with rabbit or horse IgG.

The method of Hay et al. (1975) also used rabbit IgG as the absorbent.

The modification of this method described by Carson et al. (1977) uses human Fc absorbed on plastic tubes as the absorbent, and labelled Fab'2 fragment of anti-human IgG Fab fragment to measure the IgG-RF, thus avoiding several errors inherent in the original method. The values obtained by these methods are, however, in very arbitrary units and are very dependent on the exact weight of labelled specific antibody added. The method of Carson et al. (1977) is also very complex, and these authors deduce from their results, which are expressed as the ratio between the mean values for normal and rheumatoid groups, that the IgGantiglobulin values in both seropositive and seronegative rheumatoid patients are not sufficiently above normal to make them of any diagnostic value for an individual patient.

The method of Torrigiani et al. (1970) is the only one to give absolute values for the IgM, IgG, and IgA antiglobulins separately, but, in addition to possible errors due to the use of a heterologous antigen as the absorbent, Carson et al. (1977) have also pointed out that the values for IgG antiglobulins obtained by this method will be high if much IgM antiglobulin is also present due to $(a)$ non-antiglobulin IgG combined with IgM-RF binding to the absorbent and then being measured as IgG-antiglobulin, and $(b)$ interaction of IgM-antiglobulin with the IgG of the anti-IgG serum in the gel during radial immunodiffusion.

A similar method has been described by Bianco et al. $(1971,1974)$ using insolubilised human IgG as 


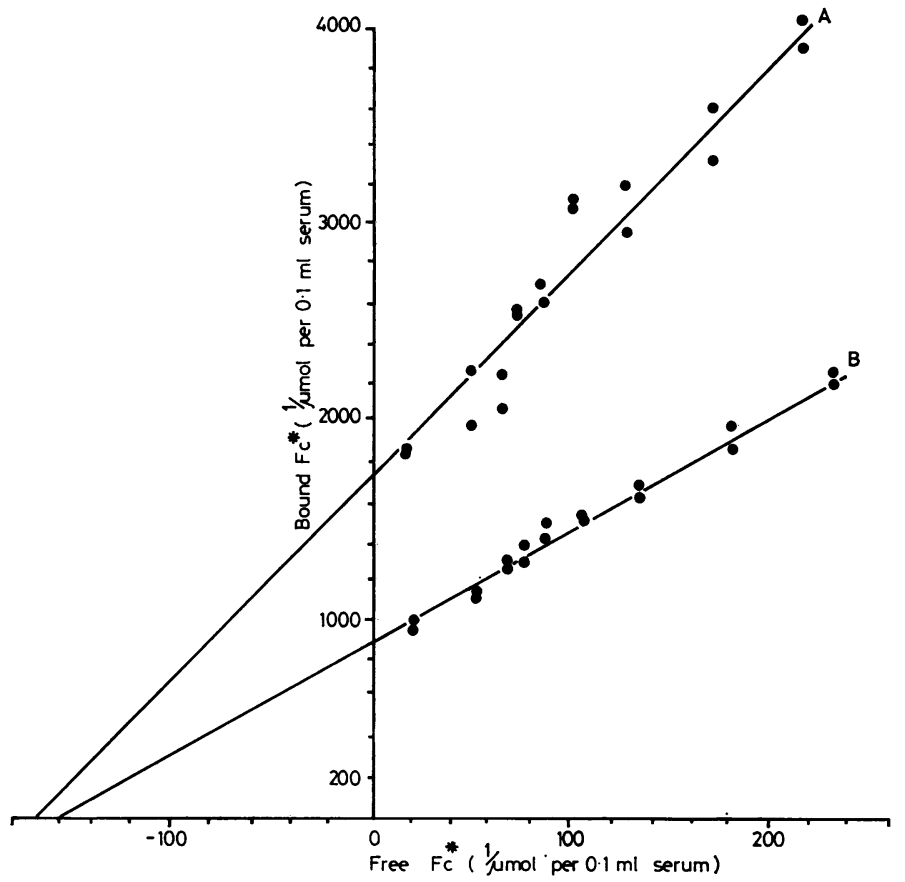

Fig. 4 Reciprocal of bound $F^{*}$ plotted as a function of reciprocal of free $F^{*}$ in supernatant for a pooled normal serum $(A)$ and a single $R A$-seronegative serum $(B)$ (duplicate values in every case). The normal serum contained $10 \mathrm{mg} I \mathrm{IG}$ per $\mathrm{ml}$, the $R A$ serum $13 \mathrm{mg}$ IgG per $\mathrm{ml}$. the absorbent, but in the 1971 paper this was applied to juvenile rheumatoid arthritis only, where the immunopathology is different from that of the adult disease, and in the 1974 paper, which included studies on seropositive and seronegative adult RA cases in addition, the experimental method precluded the obtaining of absolute values.

The presently described method is not subject to the inherent inaccuracies of either the absorption, elution, and radial immunodiffusion method of Torrigiani et al. (1970) or the solid phase radioimmunoassay of Hay et al. (1975), as discussed by Carson et al. (1977), since it uses human Fc fragment as a direct competitor with the IgG of the serum for the antiglobulin combining sites. In earlier experiments the $\mathrm{Fc}$ was labelled with radioiodine; a number of earlier investigators have shown that iodine-labelled $F c$ reacts with serum antiglobulins and competes with intact IgG. In our experiments, iodine labelling and fluorescein labelling gave essentially the same results, but the fluorescein label is to be preferred owing to its permanence and easier measurement.

In any method of antibody measurement based on precipitation of bound antigen, as in Farr's (1958) original method, there is always some nonspecific co-precipitation of the antigen, which leads to relatively high and variable binding by normal sera. This is particularly so in the present method since normal sera contain small concentrations of antiglobulin in any case. Conditions are described whereby this variation is kept to a minimum while maintaining a maximum relative difference between the bindings by normal and rheumatoid sera. By calculating the logarithmic SD of the mean binding for a number of normal sera it is possible to express the value for any individual serum with $95 \%$ confdence as to whether it is within the normal range or not by taking normal mean $+2 \mathrm{SD}$ as the upper limit of this range.

Since the binding is competitive, differences in IgG content should affect the results. Measurements of total IgG in the sera were made on many occasions but no relationship could be observed. In normal and rheumatoid sera relatively low and relatively high bindings were obtained with both low and high IgG concentrations.

This apparent lack of effect of variation in IgG contents could have two explanations. Either the amount of $\mathrm{Fc}^{*}$ added is such that normal variations in IgG contents are relatively insignificant in comparison, or any increased inhibition of binding at raised IgG levels is approximately counterbalanced by increased co-precipitation due to a slightly greater amount of PEG precipitate.

The experiment with several $\mathrm{Fc}^{*}$ concentrations (Fig. 4) shows that absolute values for the total excess antiglobulin over a normal mean can be 
obtained by this $\mathrm{Fc}^{*}$ binding method, but this modification would not be suitable for routine use on a number of sera.

Munthe and Natvig (1972) have shown that the plasma cells of rheumatoid tissue contain self aggregates of IgG-RF, which do not bind aggregated IgG in the normal fashion unless the tissues are first digested with pepsin. Pope et al. (1974) have also found similar aggregates of exclusively IgG-RF in the plasma of one patient with hyperviscosity syndrome and believe the phenomenon may be more widespread. They attribute this exclusiveness to the higher association constant which would prevail for a second attachment between two molecules (Crothers and Metzger, 1972). The plasma IgG-RF aggregates do, however, bind aggregated IgG to the extent of $90 \%$. Since aggregated IgG and monomeric IgG possess the same association constant for RF (Normansell, 1971), Fc* fragment would be expected to bind, or compete with IgG, equally on these aggregated RF-IGGs as on non-aggregated IgG-RF.

Should any significant fraction of the plasma RF be self-associated with high association constant one would expect to find either that the mean value of the $\mathrm{K}$ determined for the displacement reaction falls far below unity, whereas it was in fact approximately unity, if there is any displacement at these high $\mathrm{K}$ sites, or if there is not that the total concentration of RF binding sites measured is far less than expected. There is no evidence in our results of either of these, so it must be concluded that high association constant exclusively self aggregated IgG-RF is either not a common feature of rheumatoid arthritis or does not interfere with this assay.

We are indebted to Searle Diagnostics Ltd for a grant to one of us (I.S.), which enabled this work to be carried out. Our thanks are also due to Dr E. Huskisson, St Bartholomew's Hospital, for the supply of rheumatoid sera, to Miss B. Cant, South-West Region Blood Transfusion Service, for the supply of normal sera, to Dr C. Wharton, Birmingham University, for carrying out the ultracentrifugal analyses, and to Miss Monica Leighton, Department of Statistics, St Bartholomew's Hospital, for advice on the statistical aspects of the assay.

\section{References}

Bianco, N. E., Dobkin, L. W., and Schur, P. H. (1974). Immunological properties of isolated IgG and IgM antigamma-globulins (rheumatoid factors). Clinical and Experimental Immunology, 17, 91-101.

Bianco, N. E., Panush, R. S., Stillman, J. S., and Schur, P. H. (1971). Immunologic studies of juvenile rheumatoid arthritis. Arthritis and Rheumatism, 14. 685-696.
Carson, D. A., Lawrence S., Catalano, M. A., Vaughan, J. H., and Abraham, G. (1977). Radioimmunoassay of IgG and IgM rheumatoid factors reacting with human IgG. Journal of Immunology, 119, 295-300.

Creighton, W. D., Lambert, P. H., and Miescher, P. A. (1973). Detection of antibodies and soluble antigen antibody complexes by precipitation with polyethylene glycol. Journal of. Immunology, 111, 1219-1227.

Crothers, D. M., and Metzger, H. M. (1972). The influence of polyvalency on the binding properties of antibodies. Immunochemistry, 9, 341-357.

Dreger, E. E., Keim, G. I., Miles G. D., Shedlovsky, L., and Ross, J. (1944). Preparation of sulphuric esters of long chain aliphatic alcohols. Industrial and Engineering Chemistry, 36, 610-617.

Eisenberg, R. (1976). The specificity and polyvalency of binding of a monoclonal rheumatoid factor. Immunochemistry, 13, 355-359.

Farr, R. S. (1958). A quantitative immunochemical measure of the primary interaction between $I^{*} \mathrm{BSA}$ and antibody. Journal of Infectious Diseases, 103, 239-262.

Hay, F. C., Nineham, L. J., and Roitt, I. M. (1975). Routine assay for detection of IgG and IgM antiglobulins in seronegative and seropositive rheumatoid arthritis. British Medical Journal, 3, 203-204.

Kwapinsky, J. B. G. (1972). Methodology of Immunochemical and Immunological Research, p. 259. WileyInterscience, New York and London.

Longmire, R. G., Smith, R. S., McMillan, R., and Reid, R. T. (1971). Quantitation of IgG by the ammonium sulphate technique-I. Interference with the primary reaction between ${ }^{125} \mathrm{I}-\mathrm{Fc}$ and rabbit anti-human Fc. Immunochemistry, 8, 141-151.

McKinney, R. M., Spillane, J. T., and Pearce, G. W. (1964). Fluorescein diacetate as a reference color standard in fluorescent antibody studies. Analytical Biochemistry, 9, 474-476.

Marcus, R. L., and Townes, A. S. (1971). The occurrence of cryoproteins in synovial fluids; the association of a complement-fixing activity in rheumatoid synovial fluid with cold-precipitable protein. Journal of Clinical Investigation, 50, 282-293.

Mulligan, J. J. Jr., Osler, A. G., and Rodriguez, E. (1966). Weight estimates of rabbit anti-human serum albumin based on antigen-binding capacity. Journal of Immuno$\log y, 96,324-333$.

Munthe, E., and Natvig, J. B. (1972). Complementfixing intracellular complexes of IgG-rheumatoid factor in rheumatoid plasma cells. Scandinavian Journal of Immunology, 1, 217-229.

Normansell, D. E. (1970). Anti- $\gamma$-globulins in rheumatoid arthritis sera-I. Studies on the $22 \mathrm{~S}$ Complex. Immunochemistry, 7, 787-797.

Normansell, D. E. (1971). Anti- $\gamma$-globulins in rheumatoid arthritis sera-II. The reactivity of anti- $\gamma$ globulin rheumatoid factors with altered $\gamma$ G-globulin. Immunochemistry, 8, 593-602.

Normansell, D. E. (1972). Anti- $\gamma$-globulins in rheumatoid arthritis sera-III. The reactivity of anti- $\gamma$ globulin rheumatoid factors with heterologous $\gamma \mathrm{G}$ globulin. Immunochemistry, 9, 725-736.

Pope, R. M., Teller, D. C., and Mannik, M. (1974). 
The molecular basis of self-association of antibodies to IgG (rheumatoid factors) in rheumatoid arthritis. Proceedings of the National Academy of Sciences of the United States of America, 71, 517-525.

Porter, R. R. (1959). The hydrolysis of rabbit $\gamma$-globulin and antibodies with crystalline papain. Biochemical Journal, 73, 119-127.

Torrigiani, G., Roitt, I. M., Lloyd, K. N., and Corbett, M. (1970). Elevated IgG antiglobulins in patients with seronegative rheumatoid arthritis. Lancet, 1, 14-16.

Wood, B. T., Thompson, S. H., and Goldstein, G. (1965). Fluorescent-antibody staining. III. Preparation of fluorescein-isothiocyanate labeled antibodies. Journal of Immunology, 95, 225-229.

Zubler, R. H., Perrin, L. H., Creighton, W. D., and Lambert, P. H. (1977). Use of polyethylene glycol (PEG) to concentrate immune complexes from serum or plasma samples. Annals of Rheumatic Disease, 36, Supplement, p. 23.

\section{Appendix}

MATHEMATICAL TREATMENT OF THE FC* BINDING ASSAY

\section{Initial complexing state of antiglobulins}

The association constant of rheumatoid factor antiglobulin for IgG is in the range 3-5 $\times 10^{5} \mathrm{~mol}^{-1}$ (Normansell, 1970), and the association constant for $\mathrm{Fc}^{*}$ would be expected to be of the same order of magnitude, whereas the displacement constant for Fc* reacting with an RF-IgG complex should be in the region of unity, actually the ratio between $\mathrm{K}_{\text {ass }}$ for $\mathrm{Fc}^{*}$ and $\mathrm{K}_{\text {ass }}$ for IgG. Before considering the reaction of $\mathrm{Fc}^{*}$ with $\mathrm{RF}$ in plasma it is therefore necessary to establish the complexing state of the RF with serum IgG in the test system before addition of $\mathrm{Fc}^{*}$.

It can readily be calculated from the value of $K$ given by Normansell (1970) that with a normal average serum IgG concentration of $12 \mathrm{mg} \mathrm{ml}^{-1}$ and IgG-RF concentrations in the ranges given by Torrigiani et al. (1970), $70-80 \%$ of IgG-RF will be present as RF(IgG) $2,15-21 \%$ as RF(IgG) and only $3-6 \%$ as free RF in the seven-fold dilution of whole serum used in the test before the equilibrium is frozen by precipitation with PEG. At the higher IgG concentrations sometimes found in rheumatoid serum the percentage of uncombined binding sites will be still less.

It therefore follows that the reaction with $\mathrm{Fc}^{*}$ is predominantly one of displacement and that the bound $\mathrm{Fc}^{*}$ will be almost entirely in the form of $\mathrm{RF}(\mathrm{IgG})\left(\mathrm{Fc}^{*}\right)$ with some $\mathrm{RF}\left(\mathrm{Fc}^{*}\right)_{2}$ but practically no RF(FC*). Such complexes (cf Table 1) should be fully precipitated at the PEG concentration used in the assay.
Reaction of antiglobulin-IgG complex with $F^{*}$ *

In the following derivation the symbols refer to molar concentrations in the test system: $\mathbf{G}_{0}=$ Total concentration of non-antiglobulin IgG antigen; $\mathbf{G}=$ Concentration of free non-antiglobulin IgG in the equilibrium situation.

The IgG measured by radial immunodiffusion with anti-IgG serum will approximately equal $\mathbf{G}_{0}$ but may be slightly greater due to the presence of antiglobulin which, though complexed with normal IgG, will probably diffuse slowly. $\quad B_{0}=$ Total concentration of antiglobulin binding sites (ie, $2 \times$ IgG-antiglobulin plus $5 \times$ IgM-antiglobulin). $\mathrm{B}=$ Concentration of antiglobulin binding sites not bound to $\mathrm{Fc}^{*}$ at equilibrium (free binding sites). $\mathrm{BF}=$ Concentration of antiglobulin binding sites complexed with $\mathrm{Fc}^{*}$ at equilibrium, ie, bound $\mathrm{Fc}^{*}$, and $\mathbf{B}_{0}=\mathbf{B}+\mathbf{B F} . \mathrm{F}_{0}=$ Total concentration of $\mathrm{Fc}^{*}$ in the system. $F=$ Concentration of free unbound $\mathrm{Fc}^{*}$ at equilibrium, ie, $\mathrm{F}_{\mathbf{0}}=\mathbf{B F}+\mathbf{F}$. $\mathbf{K}=$ Equilibrium constant for the displacement reaction, the ratio, association constant of $\mathrm{Fc}^{*}$ with antiglobulin: association constant of IgG with antiglobulin.

Of these quantities, $F_{0}$ is known, $G_{0}$ can be determined (very closely) by radial immunodiffusion of the serum against gelified anti-IgG serum, and $\mathrm{BF}$ is measured in the assay.

The reaction may be represented:

$$
\text { RF-IgG + Fc* } \longrightarrow \text { RF-Fc* + IgG. }
$$

Equlibrium concentrations:

RF-IgG $=\mathbf{B}=\mathrm{B}_{0}-\mathrm{BF}$

$$
\mathrm{Fc}^{*}=\mathrm{F}=\mathrm{F}_{0}-\mathrm{BF}
$$

$\mathrm{RF}-\mathrm{Fc}^{*}=\mathrm{BF}$

IgG $(\mathrm{G})=$ Original free IgG + BF

$$
=G_{0}-B_{0} \text { (insofar as the } R F \text { is } I g G \text { ) }
$$$$
+\mathrm{BF}
$$

The complexity of this last term makes the final equation incapable of graphical solution, but the greater extent of reaction between RF-IgG and Fc*, the more nearly BF approaches $B_{0}$ and hence $G$ approaches $G_{0}$. In this solution the approximation is made that $G$ (equilibrium concentration of free IgG) equals $G_{0}$ (total $\left.I g G\right)$. Since $G_{0}$ is invariably large compared with $B_{0}$ the error hereby introduced is very small.

Now

$$
\begin{aligned}
K & =\frac{B F \cdot G}{B \cdot F}=\frac{\left.B F \cdot G_{0} \text { (approx }\right)}{F\left(B_{0}-B F\right)} \\
\frac{1}{K} & =\frac{B_{0}-B F}{B F} \times \frac{F}{G_{0}} \\
\frac{B_{0}}{B F} & =\frac{G_{0}}{F} \times \frac{1}{K}+1
\end{aligned}
$$


or $\quad \frac{1}{\mathrm{BF}}=\frac{\mathrm{G}_{0}}{\mathrm{~K} \cdot \mathrm{B}_{0}} \times \frac{1}{\mathrm{~F}}+\frac{1}{\mathrm{~B}_{0}}$

Plotting 1/BF (reciprocal of bound $\mathrm{Fc}^{*}$ ) against 1/F (reciprocal of free $\mathrm{Fc}^{*}$ ) should therefore give a straight line of slope $G_{0} / K . B_{0}$, intercept on the abscissa (condition $1 / \mathrm{BF}=0$ ) of $-\mathrm{K} / \mathrm{G}_{0}$ and intercept on the ordinate (condition $1 / F=0$ ) of $1 / \mathrm{B}_{0}$, ie, the reciprocal of the molar concentration of antiglobulin binding sites in the test system.

Evaluation of $K$ requires knowledge of $G_{0}$, which is (very nearly) the total IgG as determined by radial immunodiffusion.

Requests for reprints to: Dr G. E. Francis, Department of Biochemistry and Chemistry, The Medical College of St. Bartholomew's Hospital, Charterhouse Square, London, EC1M 6BQ.

\section{Reports and Bulletins prepared by the Association of Clinical Biochemists}

The following reports and bulletins are published by the Association of Clinical Biochemists. They may be obtained from The Publishing Department, British Medical Journal (ACB Technical Bulletins), B.M.A. House, Tavistock Square, London WCIH 9JR. Overseas readers should remit by British Postal or Money Order.

SCIENTIFIC REVIEWS (price $£ 1 \cdot 00 / \$ 2.00$ each)

1 The assessment of thyroid function March 1971 F. V. FLYNN and J. R. HOBBS

2 Renal function tests suitable for clinical practice January 1972 F. L. MITCHELL, N. VEALL, and R. W. E. WATTS

3 Biochemical tests for the assessment of fetoplacental function May 1975 C. E. WILDE and R. E. OAKEY

4 Test of exocrine pancreatic function March 1977 A. H. GOWENLOCK

TECHNICAL BULLETINS (price $£ 1 \cdot 00 / \$ 2.00$ each)

22 Bilirubin standards and the determination of bilirubin by manual and technicon AutoAnalyzer methods January 1971 BARBARA BILLING, RUTH HASLAM, and N. WALD

23 Interchangeable cells for spectrophotometers and fluorimeters September 1971 S. S. BROWN and A. H. GOWENLOCK

24 Simple tests to detect poisons March 1972 B. W. MEADE et al.

25 Blood gas analysers May 1972 K. DIxON

26 Kits for enzyme activity determination September 1972 S. B. ROSALKI and D. TARLOW

27 Assessment of pumps suitable for incorporation into existing continuous flow analytical systems November 1972 A. FLECK et al.
28 Routine clinical measurements of transferrin in human serum September 1973 K. DIXON

29 Control materials for clinical biochemistry (5th edition) September 1973 J. F. STEVENS

30 Notes on the quality of performance of serum cholesterol assays September 1973 S. S. BROWN

31 Determination of uric acid in blood and in urine July 1974 R. W. E. WATTS

32 A survey of amino acid analysers readily available in the United Kingdom September 1974 J. E. CARLYLE and P. PURKISS

33 Definitions of some words and terms used in automated analysis November 1974 A. FLECK, R. ROBINSON, S. S. BROWN, and J. R. HOBBS

34 Measurement of albumin in the sera of patients January 1975 LINDA SLATER, P. M. CARTER, and J. R. HOBBS

35 Investigation of the validity of temperature correction factors for serum aspartate and alanine transaminases March 1975 S. B. ROSALKI et al.

36 Factors influencing the assay of creatinine November 1975 J. G. H. COOK

37 A survey of enzyme reaction rate analysers readily available in the United Kingdom July 1977 R. A. SAUNDERS and R. F. BURNS

38 Transport of specimens for clinical chemistry analysis November 1977 P. WILDING, J. F. ZILVA, and C. E. WILDE

39 A scheme for the evaluation of diagnostic kits May 1978 P. H. LLOYD 